\title{
Coronavirus Pandemic and Reactions in the EU Accession Classes of 2004-2007
}

\section{Pál Dunay}

George C. Marshall European Center for Security Studies, http://www.marshallcenter.org

\begin{abstract}
This article presents the reaction of the East-central European (ECE) countries, members of the EU and NATO, to the Coronavirus pandemic. Understandably, there are major similarities as the pandemic-a global challenge-hit every state of the region, by and large, in the same way. The geographical location, size (absence of great powers), and historical traditions led to the exposure of these countries to the pandemic being closely aligned. The points of international reference of these small and medium-sized countries can be seen to align in different directions as to which other states they watch and often follow when deciding about their steps in such a global crisis. This article cannot be fully comprehensive and will, therefore, focus on the reactions of health and emergency services. It raises the question as to whether any similarities are deterministic or whether there are noticeable differences due to the variety of their political systems and current history.
\end{abstract}

Keywords: Coronavirus, pandemic, East-central Europe.

\section{Introduction}

Since the Coronavirus pandemic has hijacked the security agenda and gained priority in international politics, for the time being, speculation has been rife about how long this world change will last. Views vary: Some start out from the view that the pandemic is no more than a hiccup and, after a limited period of a few months or a maximum of two years, the world will return to "normality," particularly if a vaccination becomes available worldwide. Others are of the view that 
we face a paradigm change and that the world is entering a new era. This article takes a position somewhere in the middle and, although it is of the view that we do not face a paradigm shift, it does argue that Covid-19 will make a lasting contribution to the strengthening of those historical tendencies that have been underway for some time. Coronavirus may not change the main actors of international politics or deflect attention from disasters and their management, nor will it change the state-centric nature of the international system and the decisive role of relations among the main actors in the world at large. ${ }^{1}$ This article does not subscribe to the view that both China and the US will come out of the Coronavirus crisis weakened and that "the result will be a continued slow but steady drift toward international anarchy" in the world. ${ }^{2}$ Irrespective of which scenario will prevail, it is clear that second-rank powers and smaller ones may well have more choice to decide about their orientation and their ability to influence other actors. Exceptionally, this might also present as an ostensible choice for states in ECE. However, there is every reason to assume that most of these states will not contemplate any other options and will stay as committed to the West as they have been for the last thirty years.

It seems clear that dictatorships and autocratic regimes, on the one hand, and democracies on the other, are managing the pandemic differently (as they usually do with other manmade or natural crises). They have a fundamental difference in outlook. For democracies, "a crisis is a political test," whereas in an autocracy, "a crisis is a threat to the regime's legitimacy." ${ }^{3}$ This means that for autocracies, a severe crisis is a major challenge that may result in a sudden change of political support and hence endanger those in power. For democracies, it means far less as being in power is not usually a matter of political (and occasionally existential) survival.

This dichotomy notwithstanding, it is essential to take into consideration another factor as well. Other than the cleavage between democracies and autocracies (and the very few full-fledged dictatorial regimes we still have), this is crisis management by populist and non-populist leaders. Populist leaders have usually made attempts to belittle the importance of the problem and hence have not allocated adequate resources in a timely fashion. Due to this, they have often caused damage, including risking the lives of their people. However, beyond this, there is a major difference between democracies and autocratic regimes.

1 Richard Haass, "The Pandemic Will Accelerate History Rather Than Reshape It: Not Every Crisis Is a Turning Point," Foreign Affairs, April 7, 2020, accessed May 20, 2020, https://www.foreignaffairs.com/articles/united-states/2020-04-07/pandemic-willaccelerate-history-rather-reshape-it.

2 Kevin Rudd, "The Coming Post-COVID Anarchy: The Pandemic Bodes III for Both American and Chinese Power - and for the Global Power," Foreign Affairs, May 6, 2020, accessed May 16, 2020, https://www.foreignaffairs.com/articles/unitedstates/2020-05-06/coming-post-covid-anarchy.

3 Shlomo Ben-Ami, "Why Democracies Are Better at Managing Crises," The Strategist, May 20, 2020, accessed May 21, 2020, https://www.aspistrategist.org.au/whydemocracies-are-better-at-managing-crises. 
Whereas populist leaders of democracies sooner rather than later have to face an open society, a free press and political opposition that, in most cases, will massively mitigate against the damage of their actions, ${ }^{4}$ autocrats will have already made political opposition virtual and bought up or frightened the free press thus removing sources of lasting damage. This is where the concern clearly pronounced in the middle of the pandemic has gained importance. There has been backtracking on freedom of the press and, according to the report of Freedom House published in the middle of the pandemic, "media freedom has been deteriorating around the world over the past decade, with new forms of repression taking hold in open societies and authoritarian states alike. The trend is most acute in Europe." ${ }^{5}$ Even though the difference between democracies and autocracies remains fundamental, each of their reactions to the crisis has been significantly colored by populism.

This article presents and analyzes reactions to the Coronavirus pandemic by those East-central European states that joined the EU in 2004 and 2007. It presents the ways in which the states reacted to the health crisis and the measures they took in order to gain control over the situation and society. It would be easy to conclude that as the countries presented here are, without exception, EU and NATO member-states, they must have acted in a similar way and that they will also do the same during the recovery period and the predicted second wave of the pandemic. However, the situation is more complex.

\section{The Coronavirus Pandemic: Addressing the Health Emergency}

No state could have been totally prepared for such a large-scale health challenge that arrived in Europe with such a short advanced warning. Consequently, when we take a look at the reaction of various countries, we can work with relative results and ask what each of them could have done better. Still, the states whose response to the Coronavirus pandemic this article presents and briefly analyzes are presented as success stories nowadays with fewer people infected and, in most cases, smaller shares of deaths than in many western countries that presumably have larger and better-endowed health services than their generally poorer, East-Central European (ECE) neighbors. The question arises as to what the good news can be attributed.

Two data sets are worthy of close attention - the number of cases identified and the number of deaths resulting from the Coronavirus. In both cases, the data available shows that the ECE countries have significantly lower numbers than the larger European states, such as Italy, Spain, France, or the UK. With the exception

4 A notable exception may be Brazil where the damage seems lasting and the president has remained reckless in spite of the terrifying data and other evidence hitting the Brazilians. There are speculations to what extent the human loss will affect the president's popularity in the light of his populist attitude.

5 Sarah Repucci, "Freedom and the Media 2019. Media Freedom: A Downward Spiral," Freedom House, accessed May 15, 2020, https://freedomhouse.org/report/freedomand-media/2019/media-freedom-downward-spiral. 
of Hungary, the number of fatalities is low and, in some cases, extremely low. The reasons for this may be found not in the quantitative analysis but by taking a look at the region.

Table 1. COVID-19 in East-central Europe (June 1, 2020)

\begin{tabular}{|l|c|c|c|c|c|}
\hline & $\begin{array}{c}\text { Confirmed } \\
\text { Cases }\end{array}$ & $\begin{array}{c}\text { Confirmed } \\
\text { Death }\end{array}$ & $\begin{array}{c}\text { Confirmed } \\
\text { Death per } \\
\text { Cases (\%) }\end{array}$ & $\begin{array}{c}\text { Confirmed } \\
\text { Deaths per } \\
\text { one million } \\
\text { inhabitants }\end{array}$ & $\begin{array}{c}\text { Life expec- } \\
\text { tancy in } \\
\text { years }\end{array}$ \\
\hline Bulgaria & 2,519 & 140 & 5,6 & 20 & 75.0 \\
\hline Czechia & 9,286 & 321 & 3.5 & 29.9 & 79.3 \\
\hline Estonia & 1,870 & 68 & 2.75 & 55.3 & 77.4 \\
\hline Hungary & 3,892 & 527 & 13.5 & 53.9 & 76.7 \\
\hline Latvia & 1,066 & 24 & 2.25 & 12.75 & 75.4 \\
\hline Lithuania & 1,678 & 70 & 4.17 & 25.6 & 75.5 \\
\hline Poland & 24,165 & 1,074 & 4.44 & 28.0 & 78.3 \\
\hline Romania & 19,398 & 1,276 & 6.57 & 59.89 & 76.0 \\
\hline Slovakia & 1,522 & 28 & 1.83 & 18.38 & 77.8 \\
\hline Slovenia & 1,473 & 109 & 7.39 & 51.84 & 81.4 \\
\hline Total & $\mathbf{6 6 , 8 6 9}$ & $\mathbf{3 , 6 3 7}$ & $\mathbf{5 . 2}$ & - & - \\
\hline
\end{tabular}

Source: Johns Hopkins Coronavirus Resource Center.

The ten states have a number of similarities as far as both their past and present are concerned:

1. For several decades these states were so-called socialist countries where the organization of the society gave priority to accepting and following rules and obedience. Although the ancien regime has been over for nearly three decades, and the societies have enjoyed a taste of freedom, old routines have remained, especially in the older generations. As it is this generation that is the most endangered by the pandemic, their self-discipline in following the measures introduced, such as social distancing, staying at home and not going out without particular reason, and wearing masks were certainly part of the relative success.

2. In addition, there is another factor that will require scientific analysis: The level of vaccination in these countries has always been quite high, both historically and currently. Two examples are the numbers vaccinated with Bacillus Calmette-Guérin (BCG) against tuberculosis over many years and those currently who have the regular flu vaccination. There is no scientific evidence yet, but there is wide-ranging speculation about the positive effect of the BCG vaccine in keeping the Coronavirus symptoms under control. It can be taken for granted that further analy- 
sis will follow to see if there is a correlation between the two not so much as far as contracting the virus is concerned, but as far as the severity of the symptoms and the lethality of the outcome.

3. There is, also, another historical fact that needs to be considered, which is that, during their communist past, the socialist countries had lowquality health services as a social good with massive reserves. These health services have remained far too centered on hospitals, which is one of those characteristic features that the European Union has often criticized. Activities, such as one-day surgeries were, usually, insufficiently wide-spread and, even today, there are still too many hospital beds. If we take a look at the statistics, the conclusion is clear: "Hungary (6th), the Czech Republic, Poland and Lithuania (7th to 9th) all are in the top ten of the world's countries with most hospital beds per thousand inhabitants and Slovakia (11th) is just outside the top ten." ${ }^{6}$ Thus, this insufficiently radical modernization of healthcare worked in favor of the countries of the region during the pandemic.

Leaving historical considerations aside, it is important to note that the population of the ECE still has a shorter life expectancy than many of the "old EU member-states" or even the EU's prodigal son, the UK. Among the $27 \mathrm{EU}$ member-states, Slovenia, with the highest life expectancy in the ECE, is the 9th in the $\mathrm{EU}$, and others are significantly further down on the list. However, there is good news: Life expectancy has been rising in these countries during the last two decades. There are a number of reasons for this favorable data.

The quality of the health services in the ECE varies but, generally, trust in their ability to deliver in the case of a large-scale health emergency has been rather low. Consequently, the population had an additional incentive to be vigilant. As the Health Minister of the Czech Republic said: "We were sure our hospitals were not able to withstand the situation. We had to react." 7 Three states were identified, eventually, as not being able to manage the pandemic if the needs of intensive care units (ICU) and ventilators increased rapidly: Bulgaria, Hungary, and Romania. As Veronica Anghel said, in their situation, "any increase in cases will tip the system over." ${ }^{8}$ Other countries had somewhat less reason to worry, but

6 The data on hospital beds reflect the situation in 2017. Bojan Pancevski and Drew Hinshaw, "Poorer Nations in Europe's East Could Teach the West a Lesson on Coronavirus," The Wall Street Journal, April 12, 2020, accessed May 16, 2020, https://www.wsj.com/articles/poorer-eastern-european-nations-could-teach-thewest-a-lesson-on-coronavirus-11586718779.

7 Dénes Albert, "Hungary, Poland and Other Eastern European Countries Are Faring Better with Coronavirus for These Reasons," Remix News, April 29, 2020, accessed May 16, 2020, https://rmx.news/article/article/hungary-poland-and-other-easterneuropean-countries-are-faring-better-with-coronavirus-for-these-reasons.

8 According to Romanian political scientist Veronica Anghel quoted by Shaun Walker and Helena Smith, "Why Has Eastern Europe Suffered Less from Coronavirus than the West?," The Guardian, May 5, 2020, accessed May 16, 2020, www.theguardian.com/ 
they faced other concerns such as the need for state of the art equipment and medical personnel.

As far as medical equipment is concerned, the countries of the region recognized their shortcomings and began to import whatever they could. This usually meant the acquisition of protective gear (masks and gowns), COVID-19 test equipment, and ventilators from China though later, they were also sourced from elsewhere. The Czech Republic showed the way in the region by being the first to send a special plane to China to collect equipment. It was followed by others when the pandemic hit them, who also noticed that China was able to meet the need when potential suppliers in Europe were short of equipment. Although other countries began to export later, in March, there was a monopolistic market. Other EU member-states were busy trying to meet their own pandemic challenge and, as a protective measure, introduced export bans in order to meet their domestic needs. The need in other European countries emerged simultaneously with that in the ECE countries, so the reliance on Chinese imports was a reflection of the fact that Beijing was in a different phase of the pandemic curve and under the impression that it has already overcome the crisis (which was, to some extent, an overestimation). Later, some of the ECE countries, as well as some of the states further to the West, concluded that the imported material and equipment from China was substandard and expressed their dissatisfaction. However, their reactions varied. Czechia was the most forthcoming, clearly expressing their views, as would be normal in any business deal (similarly to the Netherlands) while others were more careful, and some rather timid. Hungary, for instance, satisfied itself with some ambiguous statements and left a vaguely formulated quality concern for the chief medical officer rather than eliciting a response from a person more directly associated with the government.

As far as the availability of medical personnel was concerned, many ECE countries faced a challenge due to a shortage of qualified medical personnel, including physicians. This was due to the combination of the free movement of labor in the European Union along with low pay in the ECE for professions that are easily transferable internationally. The ECE states were lucky that a full-blown pandemic did not hit them at full force. Thus, they did not face a situation in which they would not have been able to react because of a shortage of personnel. Of course, temporary extra pay and some other measures, such as giving recognition to the extraordinary efforts in the health sector, helped. However, this crisis has also identified lasting structural problems. It is open to question whether these states will have learned from this experience and will introduce lasting measures to address the problem before an eventual second wave of the pandemic hits. This would require significant increases in monthly pay so that nurses would not be obliged to survive on $€ 400$, and medical doctors on $€ 1,200$. If this does not change, the outflow of professionals, that has been going on for

world/2020/may/05/why-has-eastern-europe-suffered-less-from-coronavirus-thanthe-west. 
some years, will continue. ${ }^{9}$ Last but not least, it will be necessary to train more medical professionals. In some cases, this had already begun when early signs of emigration from the medical sector started some years ago. However, when the shortfall of medical doctors reaches 50-60 percent, there is no remedy. Most of those who leave pursue a career in their profession in western Europe. The market is clearly able to continue to absorb further professionals in some of the wealthiest western European states - from the UK through Scandinavia to the German-speaking part of Europe.

It is understandable that the ECE states, being poorer than their more fortunate fellow EU members further to the West, spend less on the health sector. The fact that they also spend less on purchasing power parity (PPP) is somewhat troubling. However, the gap between the OECD average spending $(\$ 3,994)$ and the spending in ECE countries is not striking. It ranges between $\$ 3,068$ (Czechia) and $\$ 1,749$ (Latvia). ${ }^{10}$ Still, due to the high mobility of medical professionals, adequate attention needs to be paid to this matter. In some countries, extra spending does not make as much of a difference as it ought. This is because tenders for the procurement of medical equipment and material are affected by corruption and so expenses rise without a commensurate improvement in quality. Rather than skimming the surface of the problem, the roots have to be addressed.

When summing up the experiences drawn from the reaction of the ECE states to the spring 2020 outbreak of the Coronavirus pandemic, it is possible to conclude that although most states faced one shortfall or another, none of them faced an unmanageable challenge. It is open to question whether this "soft warning" will result in a further prioritization of health services so that these countries, like Baron Münchausen, will manage to pull themselves out of trouble. What adds to the difficulty is that health care is a national competence in the EU, which means that member-states cannot count on more than soft persuasion from their EU partners unless consensus can be achieved to revise the rules.

In several ECE countries (and not only there), it was noticeable that the governments did not learn the lessons taught regularly at conflict management training courses. Priority has to be given to the protection of first responders; in this case, people working in the health service. The second most important layer of protection has to focus on the most vulnerable people, like those living in elderly care homes. Complaints were wide-spread in the health sector, particularly

9 The Romanian Ministry of Health estimated that 43,000 medical doctors left the country between 2007 and 2018. See Shaun Walker, "Romanian Hospitals in Crisis as Emigration Takes Its Tall," The Guardian, April 21, 2019, accessed May 16, 2020, https://www.theguardian.com/world/2019/apr/21/romanian-hospitals-in-crisis-asemigration-take-its-toll. The numbers of economic migrant physicians is massively smaller but demonstrate a similar problem.

10 Health Expenditure per capita, 2018 (or nearest year), OECD, "Health at a Glance 2019: OECD Indicators," Paris, OECD, 2019, accessed May 20, 2020, https://www.oecdilibrary.org/social-issues-migration-health/health-at-a-glance-2019_4dd50c09-en. No comparable data is available for Bulgaria and Romania that are not members of the OECD. 
during the early phases of the pandemic. There were some small-scale scandals in various countries. A few hundred people retired from their jobs in Romania, a small-scale spontaneous strike broke out in a hospital in Hungary as no protective gowns were available and masks did not meet the necessary standard for medical professionals. As time passed, and supplies arrived, the organization of the distribution of protective equipment gradually improved.

Successful protection against Coronavirus also depended upon the readiness of various countries to learn from the example of others and to react rapidly. It can be taken for granted that when this crisis is analyzed, which state learned from which partner and which are the "brand names" in healthcare will be identified. According to a Russian political scientist, the "test of the virus was best passed by those states that are not concerned with constant proof of their exclusivity, but are focused on creating safe and comfortable living conditions for their citizens" 11 This might also be a matter for many ECE countries as they are usually policy-taker or policy-shaper states and do not have excessive collective egos that would prevent them from being ready to learn. What did contribute to success was how well the political classes reacted and whether they provided an example in respecting the protective measures. There were no particular surprises, although some states definitely performed better than others. It is sufficient to say that Slovakia did well on both counts. It learned from Czechia and thus gained valuable time to react as the pandemic evolved. Lockdowns started in a timely manner, e.g., in Czechia six days before the first death from Coronavirus. In Slovakia, when the new cabinet was sworn in, everybody wore a mask in Bratislava, and, at the inauguration of the country's President, she started a fashion with the mask harmonizing with her dress. While the so-called Visegrad countries were ready to learn from each other and their immediate western neighbors, others, with different geographical locations, appear to have drawn somewhat different conclusions. Estonia, an exemplary transformational country, has indicated that it would apply a more selective lockdown that would be less harmful to the economic interests of Tallinn if the Coronavirus pandemic returns. ${ }^{12}$ This is clearly a lesson that could be learned from Sweden that chose to pursue "herd immunity" rather than isolation and applied it relatively successfully.

In addition to the above, the issue of how many Coronavirus tests various countries could carry out was a major and often divisive factor. There were a number of reasons for this:

11 Igor Zevelev, "The post-COVID weakness of the superpowers," Kommersant, May 31, 2020, accessed May 31, 2020, in Russian, https://www.kommersant.ru/doc/43640 43?from=main_9.

12 “May Blog: Coronavirus in Estonia," Estonian World, May 31, 2020, accessed June 1, 2020, https://estonianworld.com/life/blog-coronavirus-in-estonia. 
1. In an early phase, there was an apparent shortage of test kits available. Then, when further supplies became available, doubts were raised about the reliability of the test kits imported from China.

2. As is apparent - tests do not directly save lives. But without them political decisions might be taken, which could have massive, inherent risks of miscalculation.

3. However, if few tests are carried out, many cases do not appear in statistics and hence records of the number of infections can be kept low. This was of concern particularly in those countries where the fatality rate was high compared to the total number of cases. As the pandemic progressed, most ECE states appeared to understand the importance of testing and the access to reliable information. However, early differences, such as those between Czechia and Hungary, remained. ${ }^{13}$

The management of the pandemic brought the governmental agencies responsible for this sector into the limelight. In some cases, ministers had to take political responsibility for situations they had little to do with such as the delayed payment of bonuses to health professionals, or when some of them got into the crossfire due to their good, professional conscience, requesting comprehensive testing of the population of the capital city. ${ }^{14}$ In other countries, the consequences were more severe, like in Hungary, where the minister responsible for health services instructed 36,000 hospital beds to be vacated (approximately 60 percent of the total number available); some of them were not occupied, but many were which resulted in some untimely or unnecessary deaths of patients. Later, this brutal measure was eased and 12,000 hospital beds were returned to non-Coronavirus use. ${ }^{15}$ When the government realized that it would be difficult to avoid a scandal, the Minister of Human Capacities was sent to the Parliament with the message that no hospital had been obliged to vacate hospital beds. One might question whether this was a flat lie, as the opposition stated. And, if one were to consider what happened to the hospital directors, one might conclude that it was. However, if one were to take a look at the text of the ministerial instruction, then the situation becomes more complicated. Indeed, the instruction to hospitals was to vacate 60 percent of the hospital beds by April 15. How-

13 For an early account see Shaun Walker and Christian Davies, "Lack of Testing Raises Fears of Coronavirus Surge in Eastern Europe," The Guardian, March 29, 2020, accessed May 16, 2020, https://www.theguardian.com/world/2020/mar/29/lack-oftesting-raises-fears-of-coronavirus-surge-in-eastern-europe.

14 For more details see the analysis of Matthew Rhodes and Valbona Zeneli, "COVID-19 and Southeast Europe," Security Insights 58, May 2020, accessed May 22, 2020, www.marshallcenter.org/en/publications/security-insights/covid-19-and-southeasteurope-0, mentioning Bulgaria and Romania, respectively.

15 Anna Danó, "During Eight Days Hospitals Have to Vacate Approximately 36 Thousand Beds," Népszava, April 9, 2020, in Hungarian, accessed April 15, 2020, https://nepszava.hu/3074040_koronavirus-nyolc-nap-alatt-mintegy-36-ezer-agyatkell-kiuriteniuk-a-korhazaknak. 
ever, the third paragraph of the instruction said: "All patients should be transferred to another institution where this is justified by the patient's care needs." 16 As nobody tried to move patients that needed further treatment around to other hospitals, it would be difficult to decide how the ministry might have reacted if hospitals had started to move any severely ill, non-COVID-19 patients that could not be returned home around to other hospitals. It is essential to note that there is one part of the government structure that has performed quite well and that is communicating messages, which could not be identified as contradicting the facts.

Beyond the circumstances outlined above, it is useful to conclude that the success of effectively fighting a crisis like the Coronavirus pandemic depends upon a few simple matters. It requires timely decisions, early action by the authorities, and honest and reliable communication. The unity of the political class, putting earlier divisions aside, also helps as the example of several countries has demonstrated.

\section{Conclusions}

The ECE states have withstood the Coronavirus pandemic of spring 2020 better than many other countries, both in Europe and the world at large, that are endowed with better resources and larger health care sectors. This has been due to various factors, including the early reaction of governments, the support of the population, the discipline of the most exposed, the elderly, the abundance of hospital beds, and also that the pandemic did not challenge the capacity of the health services. This was fortunate as some states in the region had shortcomings that included small material reserves and depleted professional cohorts in the medical service. None of the ECE countries tried to "reinvent the wheel" and unlike states, like Belarus, Brazil or Sweden, to follow some Sonderweg. Most ECE states tried to constrain individual freedoms to a necessary extent and then gradually lifted the restrictions, such as international travel in the EU, in coordination with their neighbors.

It has remained inconclusive whether every ECE state has learned the lessons of the pandemic and has drawn conclusions for addressing critical shortfalls such as the retention of medical professionals by improving pay and working conditions. Many governments have begun to consider these issues but it would be premature to state whether action will follow or whether a political compromise will water down the necessary solutions. Without these changes, some ECE countries may face severe challenges if the pandemic returns again and is more fatal than before.

16 "Utasítás COVID-19 fertőzött betegek ellátására alkalmas ágykapacitás bővítésére/Instruction to expand bed capacity to care for COVID-19 infected patients," Emberi Erőforrások Minisztériuma / Ministry of Human Capacities, IV/3220/2020/ EFFHAT, April 7, 2020, accessed May 29, 2020. Available at www.portfolio.hu/ gazdasag/20200521/koronavirus-kasler-miklos-mondatat-sajat-levele-cafolja-meg433100. 


\section{Disclaimer}

The views expressed are solely those of the author and do not represent official views of the PfP Consortium of Defense Academies and Security Studies Institutes, participating organizations, or the Consortium's editors.

\section{Acknowledgment}

Connections: The Quarterly Journal, Vol. 19, 2020 is supported by the United States government.

\section{About the Author}

Dr. Pal Dunay is Professor of NATO and European Security Issues at the Marshall Center and Academic Advisor of its PASS, ESS-E, and SES courses. He was Director of the OSCE Academy between 2014 and 2016, Course Director of the International Training Course in Security Policy at the Geneva Centre for Security Policy (GCSP) between 1996 and 2004 and again between 2007 and 2014, Director of the Hungarian Institute of International Affairs in 2007 and senior researcher at the Stockholm International Peace Research Institute (SIPRI) between 2004 and 2007.E-mail: pal.dunay@marshallcenter.org. 